\title{
語明度の変化要因と補経物
}

第 3 報 唇裂・ 口蓋裂患者について

岡原 和信 倉知 正和 丸井 義仁 桑原 勉
藤本 明伸 山崎 善英 藤井 輝久

\section{Prosthetic Aspect of Articulation Change}

Part 3. Speech Improvement in Cleft Lip and Palate Patient

\begin{abstract}
Kazunobu Okahara, Masakazu Kurachi, Yoshihito Marui, Tsutomu Kuwabara,
\end{abstract} Akinobu Fujimoto, Yoshihide Yamazaki and Teruhisa Fujii

\section{I. 緒 言}

唇裂・口蓋裂患者では, 閉鎖手術後に口唇形態不良な どから,再度口唇形成術を行うことが少なくなく,前回の 形成手術の目安として装着してあった義歯が, 不適合, あるいは不調和を来たすことがある.このような場合， 義菌の前歯部人工歯の調整あるいは再製が必要となる. 従来から，唇裂・口蓋裂の補緅の症例報告は多数みら れるが1 8), 口唇形成術後の補緅物の調整, あるいは再 製についての報告はみられない.

そこで今回われわれは，再度の口唇形成術による義歯 の前歯部人工歯と, 口唇との不調和からくる審 美障 害 と, 若干の発音障害を主訴として来院した唇裂・口蓋裂 患者に，新たに改善を加えた義歯を製作した症例を報告 するとともに，その義歯への適応に関する客観的評価方 法として, 旧義歯を対照に語明度試験を行い, 若干の考 察を行った.

\section{II. 症例の概要}

患者は 21 歳の男性で, 第 1 回目の来院は昭和 51 年 3 月 23 日であった. 主訴は, 前述のごとく口蓋開鎖術,

岐阜歯科大学歯科補緅学第 2 講座 (主任 : 光井敏郎教授)

The Second Department of Prosthetic Dentistry Gifu College of Dentistry (Chief : Prof. Toshiro Mitsui) 昭和 55 年 4 月 18 日受付
口唇形成術後の審美および発音障害である. 家族歴, 既 往歴ともに特記事項はない. 現病歴としては, 1 歳と 3 歳の時, 某病院で口唇および口蓋閉鎖手術を受けた. 18 歳の時, 某大学附属病院で口唇形成手術を行い, $21 \mid 12$ 欠損部を可撤性局部床義歯にて補緅したが，口唇形態に 不満が残った. なお，患者は言語訓練の経験はない.

現症のうち, 口腔外所見では上口唇の正中部と右口 角部付近から右鼻孔人瘏痕がみられ, 口唇の不整および 宿凹感がある. 下口唇にも移植手術のためにできた瘏 痕がみられる。その他全身的所見では特記事項はない (Fig. 1).

口腔内所見では $\frac{8521}{8} \mid \frac{1278}{8}$ が欠損. 残存歯の動摇 はなく，歯肉も健康である. 咬合状態は $\frac{64}{76} \mid \frac{56}{567}$ が咬 合しているのみであり, 上顎の歯列弓は前歯部で狭窄し て， 3134 は下顎歯列の舌側に位固している. 上䫑前歯 欠損部の䫟堤は不整形で, 正中より右側人約 $10 \mathrm{~mm}$, 歯 槽頂より前方へ約 $3 \mathrm{~mm}$ の口腔前庭の位置に, 長径約 $7 \mathrm{~mm}$, 短径約 $5 \mathrm{~mm}$ の穿孔があり, 鼻腔と交通してい る. 硬口蓋, 軟口蓋および口蓋垂の正中部に瘯痕がみら れるが, 機能的にはほとんど障害はないようである (Fig. 2).

酤触歯（囵）の充媜後, 次の点に留意して義歯を製作 した. (1) 下顎歯列はほぼ正常とみて，下影前歯部を参 考にして上䫑人工歯前歯切端 の位置を決定する. (2) 前 歯部咬合平面は両瞳孔と平行. (3) 陥凹感と口腔前庭部 の穿孔をふさぐために，唇側部の床を厚くする. (4) 咬 

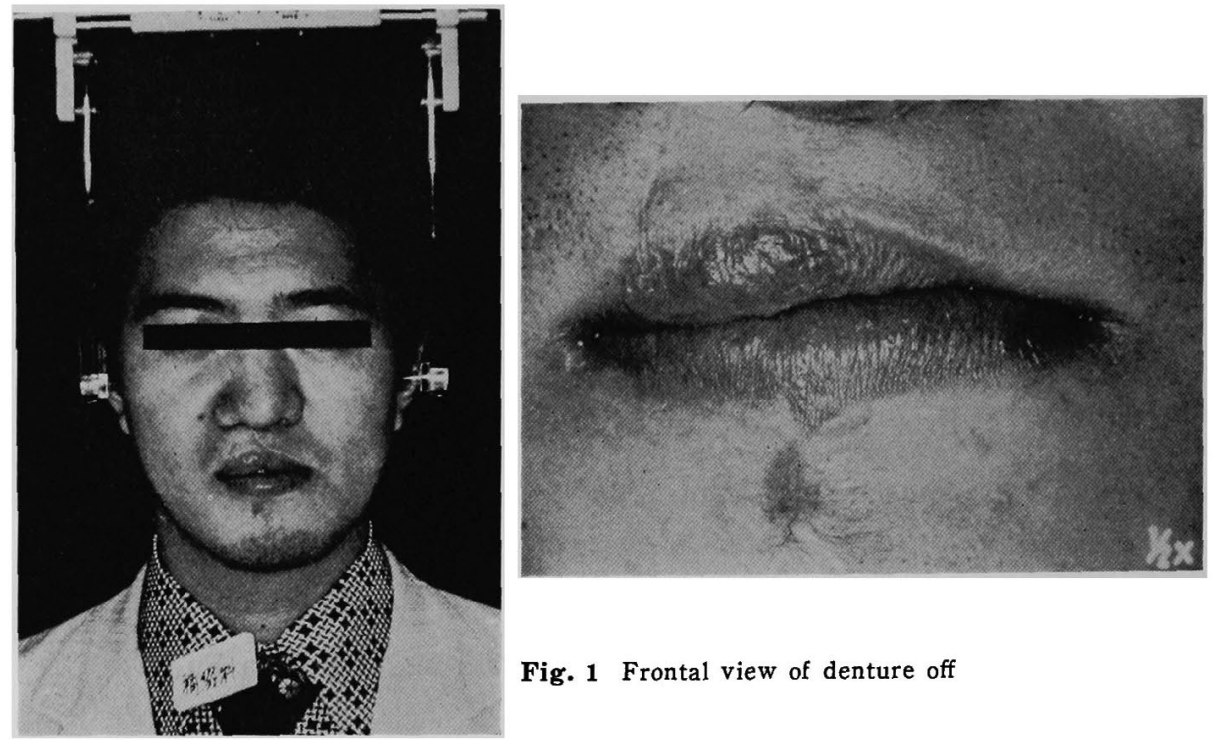

Fig. 1 Frontal view of denture off
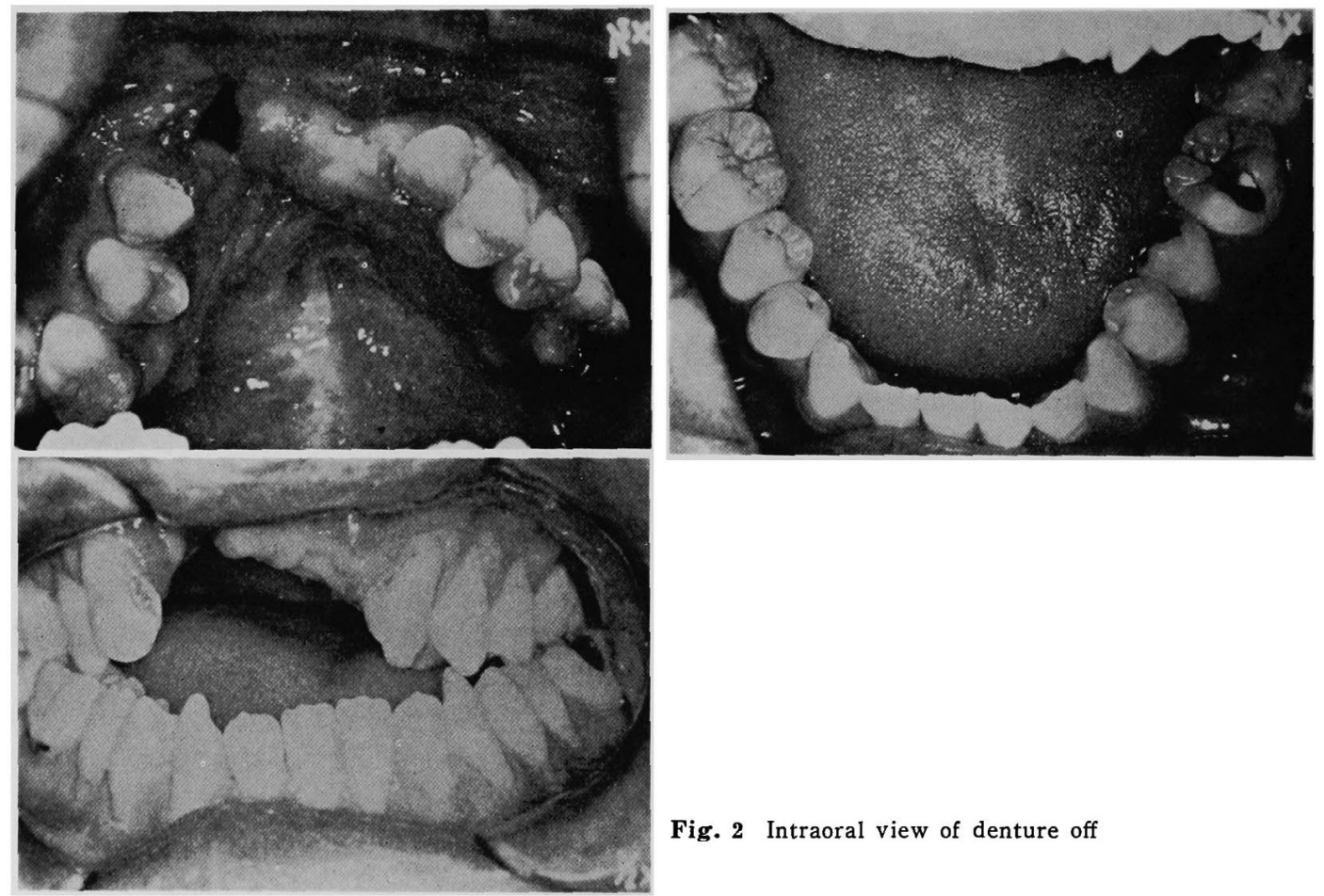

Fig. 2 Intraoral view of denture off

合高径を変えないために, 咬合している残存歯咬合面を 露出させ，対咬させる. (5) 義歯の審美性および維持, 支持をよくするため, 床をできるだけ広くして, 正常歯 列弓外にある残存歯を床内に包含する. 正常歯列内にあ る残存歯は露出させ, クラスプを設ける. (6) 発音しゃ
すくするため, 下顎歯列弓とバランスのとれた位膡の口 蓋前方に， S 隆起を設け, また床後縁はスムーズに移行 させる.このようにして製作した義歯（以下，旧義歯と 呼ふ, Fig. 3，4）を装着後, 前歯部人工歯の排列を参 考にして口唇形成術を行った. 

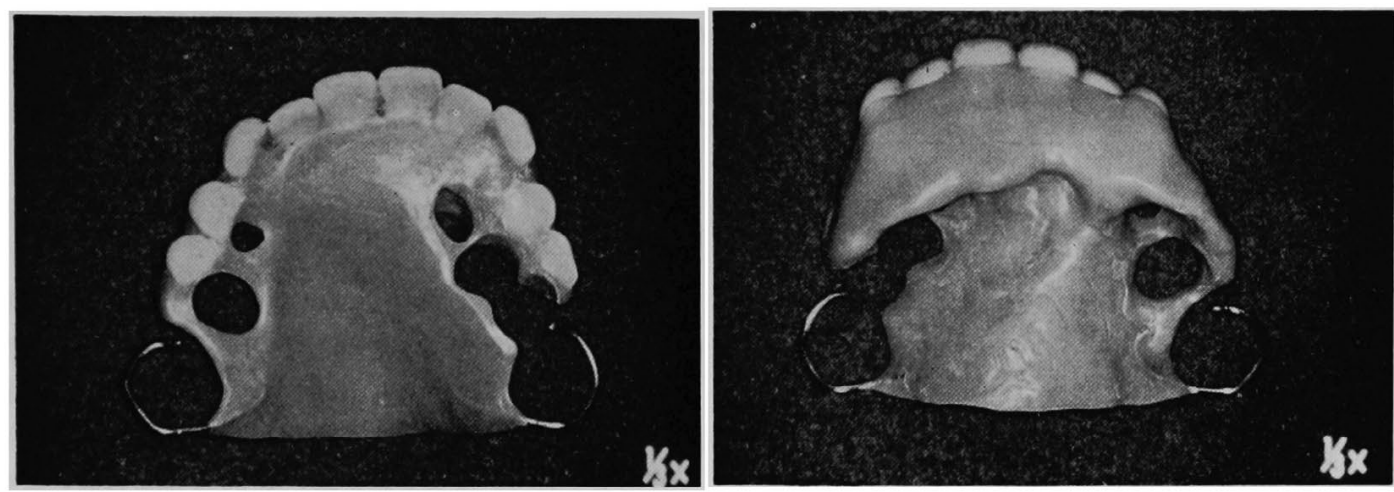

Fig. 3 Old denture
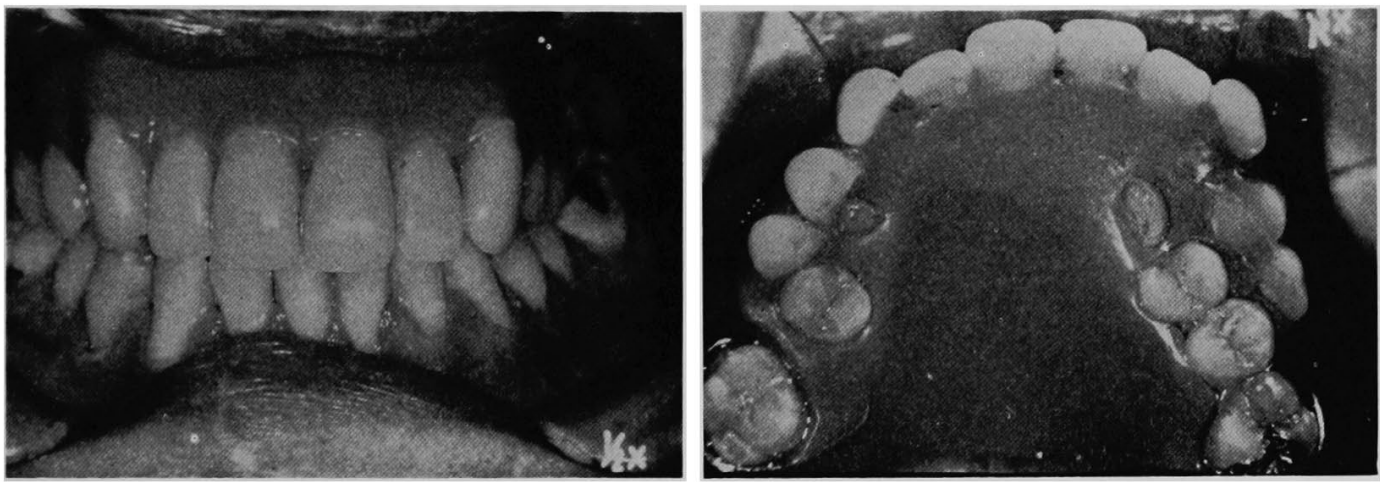

Fig. 4 Intraoral view of the old denture in

以後 2 年間, 患者は審美, 機能ともにほほ満足してい たが, 昭和 53 年 8 月, 口唇の形態に不満が生じ再度口 唇形成術を行った. この手術により, 義歯の前歯部唇側 と口唇とがやや不調和となり，口唇の陥凹感がみられる ようになったとして，昭和 54 年 5 月，再度義歯の調製 を希望した. その際患者は審美障害の他に若干の発音障 害として, $/ \mathrm{t} /$ 行音の発音不明膫を指摘していた.

そこで診查ののち, (1) 再手術による前歯部の不調和, (2) 旧義歯の疲労, (3) 旧義歯の欠点すなわち, (1) / $/ /$ 行 音が発音しにくい，回 小目菌部人工歯が咬合していな

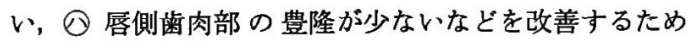
に，新義歯を製作する必要を認めた.

\section{1. 新義歯の製作}

新義歯製作において留意した点は，(1) S 隆起 と前歯 部舌面部の歯肉形成, (2) 右小臼歯部の人工歯を咬合さ せる, (3) 唇側歯肉部の豊隆を増大させるなどであり， これらの点以外は, 患者が旧義歯でほぼ満足し, 発音障 害もなく，義歯に慣れていることからことさら新しい 形態にしなくてもよいと考え，旧義菌と同じ形態をとる

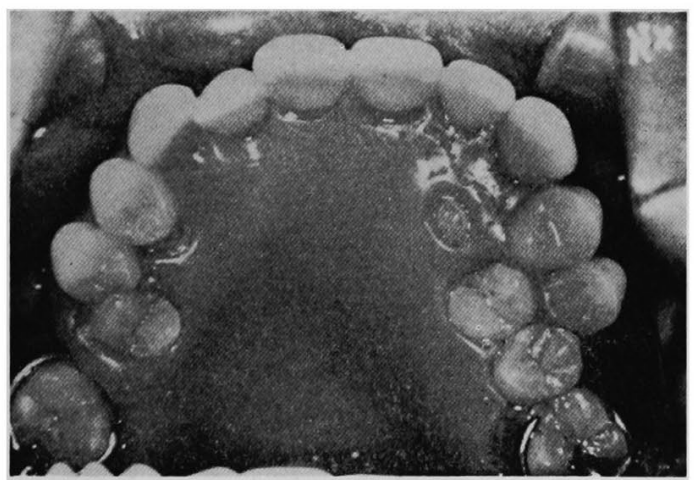

Fig. 5 Intraoral view of the new denture

ことにした (Fig. 5, 6).

Fig. 7, 8 が新旧両義歯の装着観である. 患者は口唇 の陌凹感もなくなり, $/ \mathrm{t} /$ 行音も発音しやすくなり満足 していたが，術者として新義歯に対する患者の適応を客 観的に評価する 1 つの方法として， 2 年間装着してよく 慣れた旧義歯の発音と, 新義歯のそれを対比させるため に語明度試験を行った. 


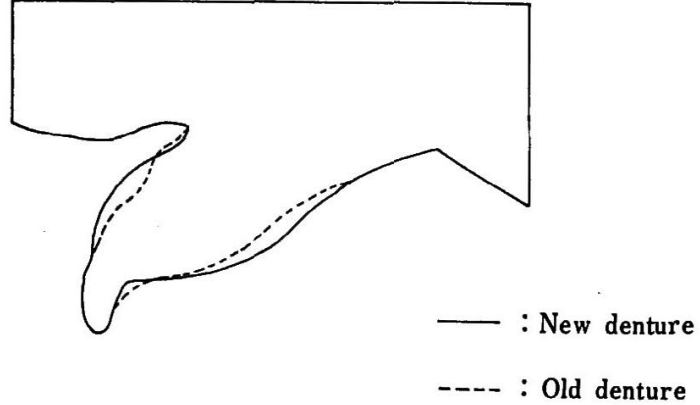

Fig. 6 Sagittal plane section

\section{2. 語明度試験}

検查語表，試験方法および装置は，桑原らによる第 2 報9)の方法と同一のものを採用した.

\section{III. 試験成精}

Tab. 1 沬義歯末装着時, 旧義歯装着時, 新義歯装着 直後, 同 1 週閒後, 同 5 週間後の各時期における語明度 で，義歯末装着時 $71.5 \%$ ，旧義歯装着時 $92.3 \%$ ，新義 歯装着直後 $88.3 \%$, 同 1 週間後 $91.4 \%$, 同 5 週間後 $91.0 \%$ となり，未装着時を除いて $90 \%$ 前後の高い值を 示している. 新義歯装着直後の語明度は, 旧義歯に比へ て有意に低下しているが，新義歯装着 1 週間後と 5 週間

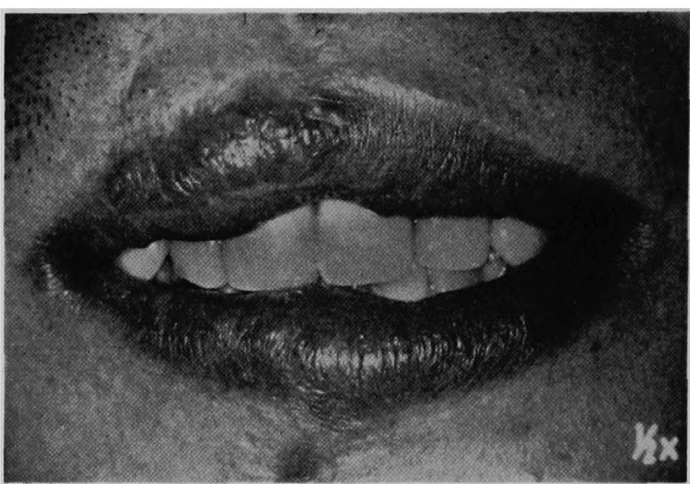

Fig. 7 Anterior view of the Old denture (left) and the new denture (right)
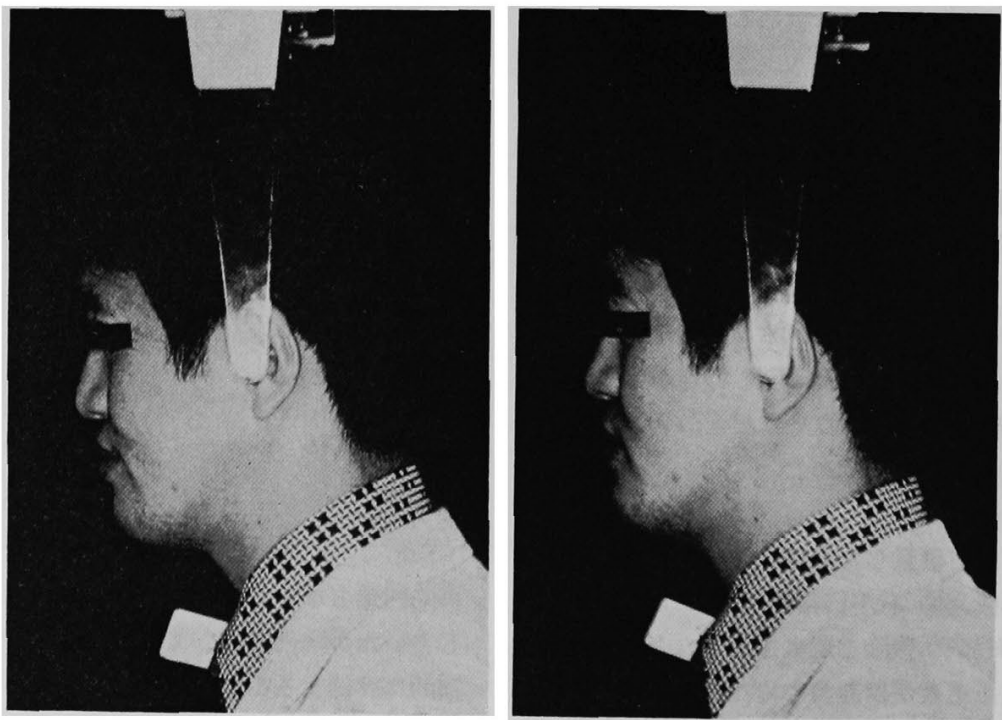

Fig. 8 Profile of the patient; the old denture in (left) and the new denture in (right) 
Tab. 1 Degree of comfortableness (Total 1,072)

\begin{tabular}{l|cccc}
\hline \hline & $\begin{array}{l}\text { number of } \\
\text { confusion }\end{array}$ & $\begin{array}{c}\text { articulation } \\
\text { score }(\%)\end{array}$ & $\chi^{2}$ & $\begin{array}{l}\text { sign of } \\
\text { significance }\end{array}$ \\
\hline Before insertion & 305 & 71.5 & 15.51 & $(+)$ \\
Old denture & 83 & 92.3 & & contrast \\
$\begin{array}{l}\text { New denture } \\
\text { immediately after }\end{array}$ & 125 & 88.3 & 9.41 & $(+)$ \\
$\begin{array}{l}\text { New denture } \\
1 \text { week after }\end{array}$ & 92 & 91.4 & 0.50 & $(-)$ \\
$\begin{array}{l}\text { New denture } \\
\text { 5 weeks after }\end{array}$ & 97 & 91.0 & 1.18 & $(-)$ \\
\hline
\end{tabular}

Significant difference compared with old denture $(p<0.05)$

Tab. 2 Articulation test of new denture (\%)

\begin{tabular}{l|ccc}
\hline & $\begin{array}{c}\text { New denture } \\
\text { imm. after }\end{array}$ & $\begin{array}{l}\text { New denture } \\
\text { 1 w. after }\end{array}$ & $\begin{array}{l}\text { New denture } \\
5 \text { w. after }\end{array}$ \\
\hline Plosive & 76.2 & $84.4^{*}$ & $84.1^{*}$ \\
Nasal & 94.4 & 90.6 & $86.9^{*}$ \\
Fricative & 99.7 & 99.3 & 97.9 \\
Affricate & 97.9 & 95.8 & 95.8 \\
Rolled & 98.8 & 95.0 & 100 \\
Vowel & 82.5 & $96.3^{*}$ & $97.5^{*}$ \\
\hline Total & 88.3 & $91.4^{*}$ & $91.0^{*}$ \\
\hline
\end{tabular}

* : Significant difference compared with new denture immediately after $(p<0.05)$

Tab. 4 Articulation test at $\mathrm{t}$-sound (\%) (Total 48)

\begin{tabular}{cccc} 
Old denture & $\begin{array}{l}\text { New denture } \\
\text { imm. after }\end{array}$ & $\begin{array}{l}\text { New denture } \\
\text { 1 w. after }\end{array}$ & $\begin{array}{l}\text { New denture } \\
5 \text { w. after }\end{array}$ \\
\hline 93.8 & 89.6 & 100 & 97.9 \\
\hline
\end{tabular}

後では旧義歯と差のない値を示している.

Tab. 2 は新義歯の装着直後, 1 週間後, 5 週間後の 語明度を構音別に分類したもので，まず破裂音では直後 $76.2 \%$ であったものが， 1 週間後 $84.4 \% ， 5$ 週間後 $84.1 \%$ とともに有意に向上している.また母音でも同様 の傾向を示している.なお通鼻音は直後 $94.4 \%$ であっ たものが， 1 週間後 $90.6 \%$ に低下し，さらに 5 週間後 には $86.9 \%$ と有意に低下している.

Tab. 3 は新義歯装着直後, 1 週間後, 5 週間後と変 化する語明度と義歯の生体への適応との関係を調べるた めに, 2 年間装着して十分慣れている旧義歯の, 口蓋前 方部の形態をことさら変えることによる発音の変化を知 る必要から，旧義㐘の口蓋前方部を厚さ約 $1 \mathrm{~mm}$ 削除 して, 削除直後, 同 4 週間後の語明度を調べたものであ る. Total に打いて削除直後は $89.2 \%$ と削除前と比べ
Tab. 3 Articulation test of old denture (\%)

\begin{tabular}{l|ccc}
\hline & Old denture & $\begin{array}{c}\text { Old denture } \\
\text { imm. after } \\
\text { adjustment }\end{array}$ & $\begin{array}{c}\text { Old denture } \\
\text { 4w. after } \\
\text { adjustment }\end{array}$ \\
\hline Plosive & 87.5 & $77.9^{*}$ & 85.6 \\
Nasal & 87.5 & 93.1 & $98.1^{*}$ \\
Fricative & 97.9 & $100^{*}$ & 99.3 \\
Affricate & 100 & $87.5^{*}$ & 100 \\
Rolled & 97.5 & 93.8 & 98.8 \\
Vowel & 96.3 & 97.5 & 90.0 \\
\hline Total & 92.3 & $89.2^{*}$ & 93.1 \\
\hline
\end{tabular}

* : Significant difference compared with old denture $(p<0.05)$

Tab. 5 Articulation test of bilabial sounds (\%) ( $\mathrm{p} \mathrm{b} \mathrm{m} \phi \mathrm{w}: 272$ )

\begin{tabular}{cccc}
\hline Old denture & $\begin{array}{l}\text { New denture } \\
\text { imm. after }\end{array}$ & $\begin{array}{c}\text { New denture } \\
1 \text { w. after }\end{array}$ & $\begin{array}{l}\text { New denture } \\
5 \text { w. after }\end{array}$ \\
\hline 83.1 & 79.0 & 82.4 & 87.1 \\
\hline$*$ : Significant difference compared \\
with old denture $(\mathrm{p}<0.05)$
\end{tabular}

有意に低下している.しかし，削除 4 週間後には $93.1 \%$ と以前と差のない語明度に回復している．同様な傾向は 破裂音と破擦音にみられ，破裂音では削除直後 $77.9 \%$, 4 週間後に $85.6 \%$, 破擦音では削除直後 $87.5 \%, 4$ 週 間後に $100 \%$ となっている.

Tab. 4 は患者が特に発音しにくいと訴えていた $|\mathrm{t}|$ 行音についての語明度を示した. 旧義歯は $93.8 \%$ の值 を示していた，新義歯は装着直後 $89.6 \%$ であったもの が， 1 週間後 $100 \% ， 5$ 週間後 $97.9 \%$ と非常に高い值 を示している.

Tab. 5 は新義歯の唇側歯肉部の豊隆増大の影響をみ るための両唇音の語明度を示した. 旧義歯 $83.1 \%$ に比 
$42-430$

べ，新義歯装着直後 $79.0 \% ， 1$ 週間後 $82.4 \% ， 5$ 週間 後 $87.1 \%$ と共に有意差は認められなかった.

\section{IV. 考察}

本症例は唇裂・口蓋裂患者でありながら，口腔後半部 の形態的, 機能的障害は少ないケースであり, 上口唇と 義㐘前歯部との不調和による審美性の回復と, 若干の発 音障害の改善が患者の主訴であった。 そこで新義歯によ り審美性を回復したうえで, 新義歯の慣れを語明度試験 を用いて考察した. 義歯の慣れを客観的に調 いる方法 は, 筋電図 ${ }^{10 ~ 13)}$, 咀礵能率 ${ }^{14,15)}$, 唓液分泌量 ${ }^{16)}$, 語明度 試験 ${ }^{17)}$ な゙種々あるが，最も容易で簡便なのが語明度試 験であると考えている.

義歯の慣れは，よく慣れていると思われる義歯の口蓋 前方部を少量削除しただけで,つまり口腔内環境を少し 変化させただけで語明度が低下し， 4 週間後は, その変 化に対し口腔周囲組織の適応により, 語明度が回復する ことで示される. その傾向は特に, 口蓋床の影響を受け やすいと言われている破裂音で顕著にみられる ${ }^{18)}$. 一方 新義歯での語明度は, 装着直後が低く, 1 週間後, 5 週 間後に有意に向上して旧義歯の語明度と比べ, 有意差の ないほどになっている.この傾向は構音別では破裂音に もみられる.これは新義歯装着直後の口腔内環境の変 化 ${ }^{19)}$ に対し， 1 週間で周囲組織の適応，すなわち新義菌 に適応したと判断できるのであろう.

また旧義歯に扔いて $\mid \mathrm{t} /$ 行音が発音しにくかったの は, / t / 行音を発音するには, 口蓋歯槽部に舌尖が接し て素早く離れなければならないが20,21), この部分の床の 厚さ，形態が不良であったことが原因の 1 つ考えられ た. そこで新義歯では, 前歯舌面の歯肉形成に考慮し, またS 隆起の豊隆をやや大きくしたことが好結果につな がったと考えられる. なお新義歯に口蓋七ダを付与しな かった理由は，口蓋七ダが構音上障害を与えるという報 告22) と, 逆に構音障害を少なくするという報告 ${ }^{23)}$ の双方 があり, 、まだ確固たる結論がないからである.

なお新義歯の唇側歯肉部の豊隆は, 正常な口唇を持つ ものには両唇音発音に対して大きな影響を受けるが20), 本症例においては，口唇不整に関する患者の意識が強 く, 日々その発音訓練の成果により, 雨唇音発音に対す る影響がなかったと考えてもよいと思う。

\section{V. 結 論}

再度の口唇形成術による旧義歯との不調和からくる審 美と，若干の発音障害を主訴として来院した唇裂・口蓋 裂患者に，新義歯を製作し，その適応に関する客観的評 価方法として語明度試験を行い次の結果を得た。

1. 未装着時の語明度 $71.5 \%$ は，旧義歯を装着する ことにより $92.3 \%$ に改善されていた.

2. 新義歯の語明度は装着直後 $88.3 \%, 1$ 週間後 $91.4 \% ， 5$ 週間後 $91.0 \%$ と， 1 週間後に有意に改善さ れた.

3. 新義歯は唇側歯肉部の豊隆を増大させたが, 両唇 音の語明度に変化は認められなかった。

4. 2 年間使用してよく慣れた旧義歯の口蓋前方部の 床を, 厚さ約 $1 \mathrm{~mm}$ 削除した直後の語明度は, 削除前 に比べて有意に低下したが，4 週間後には，削除前と差 のない値に回復した.

\section{文献}

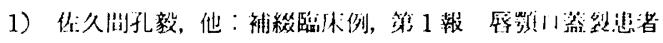

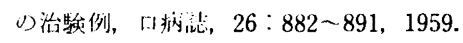

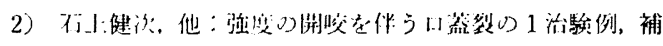

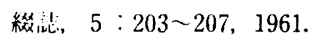

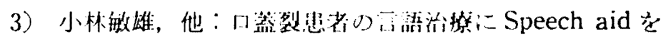

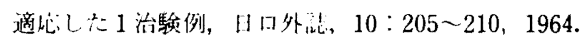

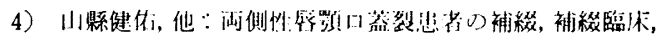
$1: 29 \sim 34,1968$.

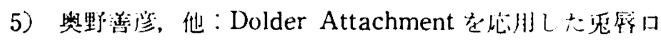

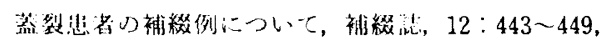
1968,

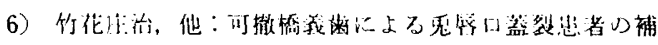
緅, 補綏臨休，2:52 -57, 1969.

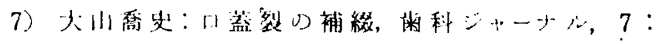
133 142, 1978 .

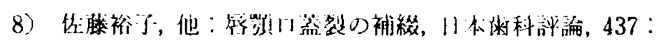
65 74, 1979.

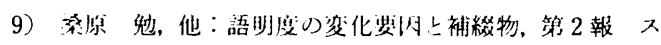

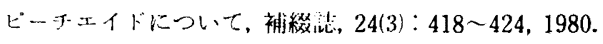

10) Tallgren, A. : An electromyographic study of the response of certain facial and jaw muscles to loss of teeth and subsequent complete denture treatment, Odont. Tidskr., $69: 383 \sim 430,1961$.

11）津留然道，他：日家製ヘーータッチメントの臨休， 
298 299, 春标, 果京, 1978.

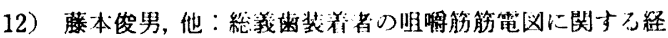
時的研究，第 1 報，補緅江： $22: 343 \sim 356,2978$.

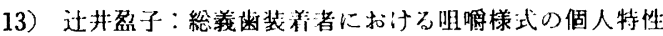

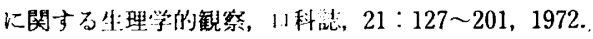

14) Vinton, R., et al. : Masticatory efficiency during the period of adjustment to dentures, J. Prosthet. Dent., $5: 477 \sim 480,1955$.

15）津留宏道，他：日家製ハーアタッチィントの臨柇， 280～283，㫪林，来宗， 1978.

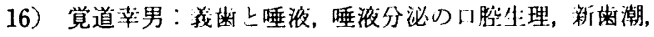
$5: 70 \sim 71,1971$.

17）別当 钽：全口蓋休に対する発音の適心に関与る実験 的研究，歯科医学，37:557 591，1974.

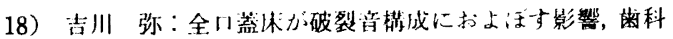
医学, 28：167 207, 1965.

19) Palmer, J. M. : Structural changes for speech improvement in complete upper deuture fabrication, J. Prosthet. Dent., $41: 507 \sim 510,1979$.

20）山縣健佑, 他：発湝機能と補経処置(その 2$)$, 補綴臨休, $9: 313 \sim 327,1977$.

21）奥田貫之，他：日本語単音のダイナミック・゙ラトグラ フィーについて, 補緅誌, $18: 143 \sim 151,1974$.

22) Allen, L. R. : Improved phonetics in denture construction, J. Prosthet. Dent., $8: 753 \sim 763,1958$.

23）桜井和人, 他：口蓋床の発音に及ほす影響について, 茵 科時報, $58: 417 \sim 423,1958$. 